\author{
KS. JAN SZPET \\ UAM POZNAŃ \\ ORCID 0000-0002-4424-0693
}

\title{
METODY KATECHETYCZNE W DYREKTORIACH Z LAT 1971-2020
}

Oficjalny dokument Kościoła, Dyrektorium katechetyczne, w trosce o przekazanie całego orędzia ewangelicznego, podając kryteria normatywne, wskazania i nadające kierunek stałego odnawiania katechezy zmierza do zapewnienia, aby katecheza nie pozostawała oderwana od kontekstu historycznego i kulturowego, w których się urzeczywistnia. Dyrektorium zawiera fundamentalne zasady teologiczno-pastoralne, zaczerpnięte z dokumentów II Soboru Watykańskiego, Urzędu Nauczycielskiego Kościoła oraz Katechizmu Kościoła Katolickiego celem opracowania podobnych dokumentów i wskazania dróg realizacji zawartych w nich postulatów w kościołach partykularnych ${ }^{1}$.

Wiele uwagi dokumenty te poświęcają metodzie, wymiarowi i elementom metodycznym. Osiągnięcie zamierzonego celu w działalności edukacyjnej oraz formacyjnej Kościoła, jaką stanowi katecheza, wymaga stosowania określonego układu czynności ewangelizatora - katechety i adresata - ucznia, uwzględnienia etapu rozwojowego uczestnika, możliwości środowiska, doboru i stosowania różnorodnych, metod, narzędzi celem realizacji wyznaczonych celów katechetycznych, treści, wymagań będących wyrazem żywotności, bogactwa, kreatywności oraz szacunku dla adresata. Wartość tych składników, metody katechezy zależy też od tego, czy i w jakim stopniu stają w służbie dialogu miłości Boga z każdą osobą, służą Objawieniu i nawróceniu, wywołują aktywność, zaangażowanie, oraz służą skutecznej asymilacji wartości i prawdy.

Analiza opublikowanych w latach 1971-2020 dyrektoriów katechetycznych pozwala dostrzec istnienie w nich pewnych stałych elementów metodycznych, choć różnie w poszczególnych okresach podejmowanych oraz zaistnienie pewnych nowych metod, wypływających z rozwoju refleksji oraz z poszukiwań dobrze ujętego przedmiotu kształcenia, rodząc model katechetycznego działania. Zmiany ujęcia łącznie z wykorzystywanymi osiągnięciami nauk świeckich, takich jak pedagogika,

\footnotetext{
1 Powstanie dyrektorium katechetycznego wiąże się z decyzją ojców soborowych, zawartą w Dekrecie o pasterskich zadaniach biskupów z 28 października 1965 r., która zaleciła stworzenie dyrektorium, mającego pomóc biskupom i proboszczom w sprawowaniu ich urzędu w zakresie katechizacji.
} 
psychologia rozwojowa, socjologia wychowania, komunikacja interpersonalna, nowe technologie - wypływające z konkretnych sytuacji Kościoła w środowisku, będące wyrazem odkrywania znaków czasu, nie są wyrazem odrzucenia wcześniejszego dorobku i tradycji, lecz naturalnej ewaluacji, wypływającej z istoty Kościoła jako żywego organizmu.

Dyrektorium z 1971 roku - Ogólna instrukcja katechetyczna, wydana przez Kongregację ds. Duchowieństwa ${ }^{2}$ - inspirowane zwłaszcza nauczaniem II Soboru Watykańskiego, w części czwartej, zatytułowanej Elementy metodologii zagadnieniu poświęca numery 70-76. Będące kontynuacją i poszerzeniem wcześniejszego, ukierunkowane pastoralnie i biblijnie Dyrektorium ogólne o katechizacji, (opublikowane w 1997 roku przez tę Kongregację ${ }^{3}$ ), wzbogacone o adhortacje Pawła VI ${ }^{4}$ i Jana Pawła II ${ }^{5}$, refleksję Synodów, poświęconych ewangelizacji i katechizacji, publikację Katechizmu Kościoła Katolickiego ${ }^{6}$ w rozdziale drugim części trzeciej, zatytułowanym Elementy metodologii poświęca numery 148-161. Natomiast inspirowane ewangelizacyjnie Dyrektorium o katechizacji, opublikowane przez Papieską Radę Ds. Krzewienia Nowej Ewangelizacji ${ }^{7}$, podejmujące nauczanie adhortacji Benedykta $\mathrm{XVI}^{8}$ i Franciszka ${ }^{9}$ poświęca zagadnieniu rozdział siódmy w części drugiej (Metodologia w katechezie) z numerami 194-223. Elementy metodyczne zostały zamieszczone też w innych miejscach dokumentów.

Niniejsze opracowanie zakłada ukazanie wspomnianych elementów metodycznych w tych dokumentach. Podejmuje następujące zagadnienia:
1. Katecheta
2. Metoda
3. Doświadczenie człowieka
4. Pamięć
5. Aktywność i kreatywność katechizowanego
6. Wspólnota

2 Kongregacja ds. Duchowieństwa, Directorium catechisticum generale, Watykan 1971; zob. też W. Kubik (red.), Katecheza po Soborze Watykańskim II w świetle dokumentów Kościoła 1, Warszawa 1985.

3 Kongregacja ds. Duchowieństwa, Dyrektorium ogólne o katechizacji, Watykan 1997; P. Tomasik, Charakterystyka „Dyrektorium ogólnego o katechizacji” w: Katecheza Kościoła w świetle „Dyrektorium ogólnego o katechizacji”, pr. zbiorowa, Kraków 1999, s. 44-65; T. Panuś, Geneza i główne wskazania Dyrektorium ogólnego o katechizacji, „Studia Katechetyczne” 13(2012), s. 11-34.

4 Paweł VI, Adhortacja apostolska Evangelii nuntiandi, Watykan 1975.

5 Jan Paweł II, Adhortacja apostolska Catechesi tradendae, Watykan 1979; zob. też W. Kubik (red.), Katecheza po Soborze Watykańskim II w świetle dokumentów Kościoła 2, Warszawa 1985.

6 Katechizm Kościoła Katolickiego, Poznań 1994.

7 Papieska Rada Ds. Krzewienia Nowej Ewangelizacji, Dyrektorium o katechizacji, Kielce 2020; zob. A. Kiciński, Rozwój dyrektoriów katechetycznych po Soborze Watykańskim II (1971-1997-2010), „Roczniki Teologiczne” 67(2020)11, s. 5-27.

8 Benedykt XVI, Adhortacja apostolska Verbum Domini, Watykan 2010.

9 Franciszek, Adhortacja apostolska Evangelii gaudium, Watykan 2013. 


\section{Język \\ 8. Przestrzeń}

\section{Katecheta}

Dyrektorium z 1971 roku wychodzi z przyjętego w dydaktyce założenia, że osobowość nauczyciela jest czynnikiem decydującym o wynikach nauczania i wychowania. Stąd kluczem do zrozumienia metodologii katechetycznej czyni stwierdzenie: „najszlachetniejsze bowiem przymioty ludzkie i chrześcijańskie katechety bardziej gwarantują owocność katechezy aniżeli wyszukane metody"10. Nie zapominając o prymacie łaski Bożej w otwieraniu się katechizowanego na wiarę przypominało, iż większą wagę należy przywiązywać do pracy katechety niż do doboru tekstów czy innych pomocy ${ }^{11}$. „Żadna metoda, chociażby bardzo potwierdzona doświadczeniem, nie zwalnia katechety z osobistego wysiłku asymilowania i oceny konkretnych okoliczności, jak również odpowiedniego przystosowania się do nich"12.

Przywołując to Dyrektorium z 1997 roku wskazuje, że do katechety należy troska o dobranie i stworzenie sprzyjających warunków niezbędnych do poszukiwania, przyjmowania i pogłębiania chrześcijańskiego orędzia przez katechizowanych, będące wyrazem łaski i wolnej ich woli, które winien wspomagać katecheta. Wobec przywiązywania wielkiej wagi do uzdolnień i autentycznego ducha katechety oraz uszanowania wolnej woli i inicjatywy katechizowanych zwraca się uwagę na niezbędność modlitwy katechety. Niezbędność modlitwy oraz świadomość wiary w Duchu Świętym winny uświadamiać, że osobowe przylgnięcie katechizowanych jest owocem łaski i wolności. Katecheta jest pośrednikiem ułatwiającym komunikację między osobami we wspólnocie i misterium Boga. Osoba oraz zaangażowanie katechety nie mogą nigdy stanowić przeszkody na drodze wiary.

Ważne są cechy typowo ludzkie takie jak: relacja katechety z katechizowanymi, pasja wychowawcza, kreatywność, przystosowanie, maksymalny szacunek dla wolności i dojrzałości osoby. Mądre towarzyszenie młodym jest najcenniejszą służbą. „Na mocy swojego mądrego towarzyszenia katecheta pełni najcenniejszą służbę w ramach działalności katechetycznej: pomaga katechizowanym w odczytaniu powołania, do którego wybiera ich Bóg"13. Wykorzystując po chrześcijańsku wkład nauk o wychowaniu swoją służbę kształtuje jako kwalifikowaną wędrówkę wychowawczą: pomaga w otwarciu na wymiar religijny oraz proponuje Ewangelię w taki sposób „by przeniknęła i przekształciła procesy rozumu, sumienia,

10 DCG 71.

11 Por. DM 17.

12 DCG 71.

13 DOK 156. 
wolności, działania, ażeby uczynić z życia dar z siebie za przykładem Chrystusa"14. Ewangelizując, wychowuje - wychowując, ewangelizuje.

Katecheci są świadkami bezpośrednimi, niezastąpionymi ewangelizatorami, którzy stanowią podstawową siłę wspólnot chrześcijańskich. Powinni charakteryzować się komunikatywnością, kompetencją, zaangażowaniem, autorytetem, dobrą relacją ze środowiskami wychowawczymi. Ich zadaniem jest kształtowanie człowieka otwartego na wezwanie Boga, Jego łaskę w celu podjęcia współpracy poprzez zawierzenie oraz refleksyjnie oceniającego zachodzące procesy $\mathrm{w}$ świetle wiary, potrafiącego wskazać motywy wyboru, inspirowane wiarą Ewangelii, pomagać kształtować właściwy system wartości człowieka kreatywnego.

Problematykę osób zaangażowanych w katechizację dokument szerzej podejmuje w swojej piątej części (217-232) oraz formacji do posługi (233-250).

Natomiast w odróżnieniu od wspomnianych dokumentów z 2020 roku w dziale poświęconym metodologii w katechezie nie wyodrębnia problematyki związanej z katechetą. Podejmuje ją w części pierwszej, poświęconej katechezie w misji ewangelizacyjnej Kościoła: katecheta (110-129) oraz formacja katechetów (130-156). Przypominając o odpowiedzialności za katechezę całej wspólnoty chrześcijańskiej w różnorodności posług, mocą sakramentów chrztu i bierzmowania we współpracy z nauczaniem Chrystusa oraz jako sługa Ducha Świętego, katecheta jest świadkiem wiary i strażnikiem pamięci o Bogu, nauczycielem i mistagogiem, towarzyszem i wychowawcą ${ }^{15}$.

\section{Metoda}

Jeden $\mathrm{z}$ istotnych elementów wpływających na efektywność procesu dydaktycznego stanowi metoda jako układ czynności podejmowanych przez nauczyciela i ucznia.

Lata po II Soborze Watykańskim w katechezie i katechetyce znaczone były poszukiwaniem odnowy co do treści, metody, sposobu komunikacji, skutecznego przekazu, mimo wcześniejszych inicjatyw. W początkowej fazie, mimo przenikania idei odnowy kerygmatycznej (podobnie jak później personalistycznej i antropologicznej, integralnej, z jej wymiarem egzystencjalnym,), żywe było panowanie neoscholastyki, klasycznej katechezy doktrynalnej, ruchu odnowy metody, szkoły pracy, choć nie można zapominać o pojawiających się formach skrajnych.

Stąd Dyrektorium z 1971 roku, a w ślad za nim to z 1997 roku, w którym pobrzmiewa akcent uwzględnienia twierdzeń psychologii dotyczący zdolności podejmowanych operacji myślowych, wskazuje metodę indukcyjną i dedukcyjną, akcentując tę pierwszą i kierując uwagę na płynące $\mathrm{z}$ niej korzyści w procesie

14 DOK 147.

15 Por. DK 113. 
katechetycznym oraz zgodność z ekonomią zbawienia i fundamentalnym prawem rozwoju ducha ludzkiego, pozwalającym przejść od rzeczy widzialnych do rzeczy obejmowanych rozumem oraz zgodności z charakterystyczną cechą poznania wiary, będącym poznaniem przy pomocy znaków. Zwraca się uwagę na logiczny, wewnętrzny tok postępowania uwarunkowanego następstwem naukowego procesu poznania. Uwzględniając je, uczeń dzięki samodzielnemu myśleniu i twórczej aktywności na drodze abstrakcji przechodzi od konkretów do pojęć ogólnych, sądów i przekonań, uogólnionych wniosków. W nowych sytuacjach życiowych potrafi dostrzec wartość poznanej prawdy dla życia. Metoda ta wskazuje na niezbędność przedstawienia faktów, zaliczając do nich: wydarzenia biblijne, czynności liturgiczne, życie Kościoła i życie codzienne, ich rozważanie i ocenę ${ }^{16}$. Stwierdzając, że wiara, pojmowana jako przylgnięcie do Boga ma dojrzewać dzięki katechezie i jako treść (przedmiot) Objawienia wskazuje normy jej przedstawiania ${ }^{17}$. Przypomniano ogólną zasadę metodyczną, że metoda indukcyjna nie wyklucza, a domaga się metody dedukcyjnej, której zadaniem jest naświetlenie i opisanie faktów wychodząc od ich przyczyn. Jednak stopień jej skuteczności uzależniony jest od poprzedzenia jej procesem indukcyjnym ${ }^{18}$.

Dyrektorium z 1997 roku, obok przywołania powyższego, wskazuje na dwa procesy działaniowe: kerygmatyczny (zstępujący misterium łaski, dane), rozpoczynający się od głoszenia orędzia wyrażonego w głównych dokumentach wiary (m.in. Biblia, liturgia, doktryna) i stosowania ich do życia oraz egzystencjalnego (wstępującego), wychodzącego od problemów i sytuacji ludzkich oraz oświecenia ich światłem słowa Bożego. Niezbędne jest uwzględnienie misterium łaski, dane ludzkie, zrozumienie wiary i proces rozumienia, kreśląc model katechetycznego działania ${ }^{19}$.

Dokument wychodził od stwierdzenia, że w przekazywaniu wiary Kościół nie posiada własnej ani jedynej metody, ale w świetle pedagogii Bożej wybiera metody danego czasu ${ }^{20}$. „Różnorodność metod jest oznaką życia i pewnym bogactwem”, a zarazem dowodem szacunku dla adresatów ${ }^{21}$. Katecheza - nie zrywając z dotychczasowym dorobkiem - jest świadoma obowiązujących zasad dydaktycznych, wypracowanych przez nauki świeckie, takie jak psychologia rozwojowa, pedagogika, socjologia wychowawcza, nauki o komunikacji. W świetle pedagogii Bożej wybiera te metody danego czasu, które nie sprzeciwiają się Ewangelii; syntetyzuje je i włącza na jej rzecz ${ }^{22}$.

16 DCG 72.

17 Por. DCG 46.

18 Por. DCG 72; DOK 150.

19 Por. DOK 151.

20 Por. DOK 148.

${ }^{21}$ CT 51; por. DOK 148.

22 Por. DOK 148. 
Nie można zapominać o niezbędności korelacji oraz wzajemnym oddziaływaniu treści i metod, wypływających z zasady wierności Bogu i człowiekowi. Wierność tę należy przeżywać tak, by nie dopuścić do jakiegokolwiek przeciwstawienia treści i metod. O wyborze metody decyduje dostrzeżenie jej wartości dla Objawienia i nawrócenia. Treść wymaga także wyboru metody odpowiedniej do natury Orędzia, do jego źródeł, języka, konkretnych okoliczności wspólnoty kościelnej i kondycji poszczególnych wiernych ${ }^{23}$. Wybór ten determinuje wychowawczy cel katechezy. Przy tej okazji przypomniano metodę wykorzystania Biblii, metodę lub „pedagogię dokumentu”, szczególnie Symbolu wiary, o ile „katecheza jest przekazywaniem dokumentów wiary", metodę znaków liturgicznych i eklezjalnych, metodę komunikacji przez środki społecznego przekazu oraz to, że „dobra metoda katechetyczna jest gwarancją wierności w stosunku do treści" ${ }^{24}$.

Dyrektorium z 2020 roku, pogłębiając przyznaje, że tajemnica wcielenia stanowi inspirację dla pedagogii katechetycznej, gdzie katecheza musi odnosić się do słowa Bożego i jednocześnie odpowiadać na autentyczne ludzkie doświadczenie $^{25}$. „Wierność Bogu i człowiekowi trzeba przeżywać tak, aby nie dopuścić do jakiegokolwiek przeciwstawienia sobie metod i treści, rozdzielenia ich czy traktowania ich jako niezależne od siebie. (...) Treści katechezy jako przedmiot wiary nie wolno poddawać jakiejkolwiek dowolnej obranej metodzie, lecz tylko takiej, która będzie odzwierciedlać naturę ewangelicznego orędzia, wraz z jego źródłami, oraz uwzględniać konkretne uwarunkowania wspólnoty kościelnej i poszczególnych ochrzczonych. (...) Wychowawczy cel determinuje wybór metodologii”26. „Różnorodność jest wymagana przez „wiek i poziom umysłowy katechizowanych, stopień ich dojrzałości eklezjalnej i duchowej oraz wiele innych indywidualnych uwarunkowań" ${ }^{27}$. Działanie łaski, spotkanie słowa Bożego z doświadczeniem ludzkim, dokonuje się za pośrednictwem człowieka. Łaska wyraża się przez znaki zmysłowe, które otwierają na misterium $\mathrm{i}$ inne nieznane człowiekowi drogi ${ }^{28}$.

Katecheza otwarta jest na korzystanie z różnych wartościowych metod, czerpiąc z pedagogiki i dydaktyki; daje się prowadzić Ewangelii niezbędnej do rozpoznania prawdy o człowieku. Świadectwem tego są różne charyzmaty posługujące słowu Bożemu, a ich owocem w historii były różne ścieżki metodologiczne, znak żywotności i obfitości ${ }^{29}$. Wartościowe dla katechezy okazują się ścieżki metodologiczne, koncentrujące się na wydarzeniach życia, jak i skierowane głównie na orędzie wiary.

\footnotetext{
23 Por. DOK 149.

24 Tamże.

25 Por. DK 194.

26 DK 194.

27 DK 195; por. CT 51; DOK 148.

28 Por. DK 196.

29 Por. DK 195.
} 
Zależy to od konkretnych osób będących podmiotami katechezy, ale ważna jest zasada współzależności, która łączy ze sobą te aspekty ${ }^{30}$.

\section{Doświadczenie człowieka}

Troska o człowieka charakteryzowała postawę Jezusa Chrystusa. Punktem wyjścia głoszonej przez Niego nauki były często najzwyklejsze wydarzenia życia codziennego, w których szukał, spotykał i przyjmował ludzi. Sygnalizował przez to istnienie rzeczywistości transcendentnej oraz wskazywał właściwą postawę. Jego postawa, wypowiadane słowa i czynione znaki zmieniały sposób myślenia, postrzegania świata i rozwiązywania problemów przez uczniów. Przebywanie z Nim stawało się źródłem licznych pytań ${ }^{31}$.

Jan Paweł II nauczał: „Kościół ma świadomość, że poprzez katechezę odpowiada na najistotniejsze pytania, które wcześniej czy później stają przed każdym człowiekiem w ciągu jego życia" ${ }^{32}$. Obserwowany rozdźwięk między wiarą i życiem skłania do uznania dwóch rzeczywistości: „doświadczenia codzienności bez Boga” i „nieobecności świata w chrześcijańskim przepowiadaniu i teologii”. Stąd katecheza, która jest wierna Bogu, nie może zapominać o elemencie antropologicznym - wierności człowiekowi. Jeśli jej orędzie ma posiadać i wykazać człowiekowi swoją życiową wartość nie może pomijać egzystencjalnych problemów człowieka. Musi starać się pomóc w znalezieniu odpowiedzi na nurtujące katechizowanych pytania i czynić je przedmiotem swoich rozważań, punktem wyjścia i dojścia dla przekazu prawdy ewangelicznej. Przez to przyczynia się do pełnego otwarcia się człowieka na zbawiającego Chrystusa i Jego Kościół. To uwalnia od patrzenia na osobę i historię wyłącznie jak na odbiorców propozycji, a otwiera na relację wzajemności i dialogu ${ }^{33}$. Przedstawiając orędzie chrześcijańskie, katecheza nie tylko ukazuje, kim jest Bóg i jaki jest Jego zamysł zbawczy, ale jak uczynił sam Jezus, objawia także w pełni człowieka człowiekowi i pozwala mu poznać jego najwyższe powołanie ${ }^{34}$.

Dyrektorium z 1971 i 1997 roku stwierdzały, że doświadczenie rodzi zainteresowanie i problemy, nadzieję, refleksje, sądy, co ma wpływ na życie osobiste. Stąd katecheza winna troszczyć się o to, by nauczyć ludzi doceniać własne, jak i społeczne doświadczenie. Może ono sprzyjać zrozumieniu chrześcijańskiego

\footnotetext{
30 Por. DK 196.

31 Por. DK 200.

32 Jan Paweł II, Wierze w Boga Ojca Stworzyciela, Watykan 1987, s. 21

33 Por. DK 197.

34 Por. DOK 116.
} 
orędzia, przyswajaniu prawd objawienia, a praktyka życia winna być naświetlona prze objawienie ${ }^{35}$.

Realizacja tego polega przede wszystkim na niesieniu pomocy w celu precyzyjnego, wyraźnego sformułowania pytań - problemów, które rodzą się w sercach słuchaczy, a następnie ukazaniu, w jaki sposób Bóg odpowiada na nie w swoim Objawieniu. Katecheza, wychodząc od człowieka, stara się uchwycić ludzkie problemy i próbuje na nie odpowiedzieć w imieniu Boga. Ujmując te problemy w świetle objawienia „ma więc uczyć wiernych patrzeć po chrześcijańsku na ludzkie sprawy, zwłaszcza znaki czasu, w ten sposób, aby mogli dzięki temu ocenić i wyjaśnić wszystko w duchu całkowicie chrześcijańskim”36. „Katecheza stanowi środek szczególnie skuteczny do zrozumienia we własnym życiu planu Bożego i poszukiwania ostatecznego sensu egzystencji i historii”37. „Należy zatem do katechezy naświetlenie tego zadania (chrześcijańskie naświetlenie ludzkiej egzystencji). Ma więc uczyć wiernych patrzeć po chrześcijańsku na ludzkie sprawy, zwłaszcza znaki czasu, w ten sposób, aby mogli dzięki temu ocenić i wyjaśniać wszystko w duchu całkowicie chrześcijańskim" ${ }^{38}$. Przy rozważaniu zasad metodycznych wspomina się: „wolno wyjść od człowieka, ażeby dotrzeć do Boga i odwrotnie”39. Ukazuje sens życia człowieka w świetle wiary ${ }^{40}$. Widoczny staje się model katechetycznego działania wychodzący od doświadczenia; jego rozważenia, przez światło słowa Bożego w świetle szeroko pojętych źródeł, prowadząc do odpowiedzi człowieka. Wymaga jednak zdolności zauważania, odczytywania i określania problemów egzystencjalnych jako problemów konkretnych ludzi, środowiska, w którym żyją i poszukiwania sposobów ich rozwiązania. Zadaniem katechezy jest uwrażliwienie osób na ich najważniejsze doświadczenia. Doświadczenie pośredniczy w przyjęciu i pogłębieniu obiektywnej treści Objawienia. Staje się środowiskiem objawienia i realizacji zbawienia ${ }^{41}$.

Oświecanie i interpretowanie doświadczenia za pośrednictwem danych wiary staje się trwałym zadaniem pedagogii katechetycznej, nie pozbawionej trudności ${ }^{42}$.

Do najpilniejszych zadań współczesnej teologii zalicza się korelację wiary chrześcijańskiej i rzeczywistości dzisiejszego człowieka. Katecheza, będąc wierną Bogu, musi być wierną człowiekowi ${ }^{43}$. Relacja orędzia chrześcijańskiego do doświadczenia ludzkiego nie jest prostą kwestią metodologiczną, ale rodzi się z celu katechezy, jakim jest doprowadzenie człowieka do komunii z Jezusem Chrystusem. Katecheza

\footnotetext{
35 Por. DCG 74, DOK 152.

36 DCG 26.

37 DCG 21.

38 DCG 26.

39 DCG 46.

40 Por. PDK 67.

41 Por. DOK 152.

42 Por. DOK 153.

43 Por. DOK 145.
} 
działa na rzecz tożsamości ludzkiego doświadczenia między Jezusem Nauczycielem i uczniem oraz uczy myśleć jak On, działać jak On, kochać jak On. Przeżywanie komunii z Chrystusem jest doświadczeniem nowego życia łaski ${ }^{44}$.

Ukierunkowanie antropologiczne preferuje indukcyjny tok nauczania. Kieruje się zasadą, że przed zrozumieniem musi wystąpić doświadczenie. Uczniowi należy przekazać prawdę samą w sobie tak, by posiadała dla niego znaczenie egzystencjalne. Przyjęcie tej zasady wymaga dostosowania do wieku i możliwości ucznia sposobu przekazu prawd objawionych, unikania języka abstrakcyjnego, starania by prowadzić do spotkania z Chrystusem.

Przewidywana zmiana postaw słuchaczy domaga się stosowania właściwych metod. Zakłada bogactwo wykorzystywanych źródeł. Materiałem katechetycznym jest uchwycone bezpośrednio zagadnienie egzystencjalne. Istnieje potrzeba stosowania korelacji oraz interakcji między głębokimi doświadczeniami ludzkimi i orędziem objawionym ${ }^{45}$.

Dyrektorium z 2020 roku doda, iż ludzkie doświadczenie ma dla katechezy znaczenie konstytutywne, zarówno w wymiarze tożsamości, jak i procesu, treści i metody ${ }^{46}$.

Człowiek współczesny żyje w sytuacjach cząstkowych, a całościowy, spójny sens jest mu trudno uchwycić, co może prowadzić do rozdzielenia przeżywanej wiary i ludzkiego doświadczenia życiowego. Katecheza na przykładzie Jezusa pomaga oświeceniu i zinterpretowaniu doświadczeń ludzii ${ }^{47}$. Jeżeli katecheza zaniecha powiązanie ludzkiego doświadczenia z objawionym przesłaniem powstanie ryzyko niebezpiecznego rozdźwięku i niezrozumienia prawdy ${ }^{48}$. Katecheza o charakterze antropologicznym posiada charakter wybitnie podmiotowy. Osoba katechizowanego oraz jego chrześcijańska formacja wysuwa się na pierwsze miejsce. Wiedza, nawet ta najważniejsza, pozostaje w stosunku służby wobec procesu kształcenia osoby.

\section{Pamięć}

Wśród elementów metodycznych w katechezie zawsze istniała świadomość niezbędności doceniania pamięci i utrwalania pamięciowego. Zmieniały się jednak sposoby podejścia i zasady. Wyrazem tego są choćby tytuły anonsujące zagadnienia w dyrektoriach. W Dyrektorium z 1971 roku są to formuly, z 1997 roku - utrwalanie pamięciowe $w$ katechezie, z 2020 roku - pamięć.

44 Por. DOK 116.

45 Por. DOK 153.

46 Por. DK 197.

47 Por. DK 199.

48 Por. DK 199. 
Dyrektorium z 1971 roku, podnosząc korzyści stosowania metody indukcyjnej, do których zalicza aktywne ćwiczenie władz i zwrot do rzeczywistości konkretnej, w wyjaśnianiu pojęć umysłowych widzi niezbędność istnienia formuł, które przemyślane i zapamiętane sprzyjają poznaniu prawdy oraz wspólnemu wyznaniu wiary. Wprowadza się je i wyjaśnia wówczas, gdy wykład i rozważania dochodzą do syntezy. Wyrażając wiernie prawdę wiary, winny one być tak dobierane, by były dostosowane do możliwości słuchaczy. Zalecano, by pilnie nauczać formuł tradycyjnych używanych do wyznawania wiary oraz modlitw ${ }^{49}$.

Natomiast Dyrektorium z 1997 roku mówi, że katecheza stanowi część „pamięci” Kościoła zachowującą żywą obecność Chrystusa. Ćwiczenie pamięci uznaje za element konstytutywny wyznania wiary, istniejący od początku chrześcijaństwa. Celem uniknięcia jedynie mechanicznego zapamiętywania zalecano wpisanie go w różne funkcje rozumienia, takie jak: spontaniczna reakcja, refleksja, chwila dialogu, milczenie, relacja ustna, praca pisemna. Przedmiotem winny być główne formuły wiary, zapewniając precyzyjny wykład, gwarantując wspólne dziedzictwo doktrynalne, kulturowe i lingwistyczne. Wskazując na przedmiot zauważa się, iż wierne orędziu chrześcijańskiemu winny być zaproponowane jako syntezy po uprzednim wyjaśnieniu. Należy uwzględnić niektóre większe formuły i teksty z Biblii, z dogmatu, liturgii oraz znane modlitwy tradycji chrześcijańskiej: m. in. Symbol Apostolski, Ojcze nasz, Zdrowaś Maryjo ${ }^{50}$.

Jako rację uzasadniającą niezbędność utrwalania pamięciowego można odczytać przywołanie z Catechesi tradendae: „Kwiaty wiary i pobożności - jeśli można się tak wyrazić - nie wzrastają w miejscach pustynnych katechizacji nie posługującej się pamięcią. Oczywiście jest rzeczą bardzo ważną, by te wyuczone na pamięć teksty zostały jednocześnie wewnętrznie przyswojone, stopniowo zgłębiane umysłem, tak by stały się źródłem osobistego i wspólnotowego życia chrześcijańskiego" ${ }^{51}$.

Dyrektorium z 1997 roku poszerza problem zrozumienia formuł i ich wyznania $\mathrm{w}$ wierze przywołując praktykę katechumenatu chrześcijańskiego jako inspirację dla katechezy w realizowaniu traditio i redditio. Pierwszemu realizowaniu powierzenia wiary drugiemu odpowiada odpowiedź podmiotu w czasie wędrówki katechetycznej i w życiu ${ }^{52}$.

Podjęte wcześniej zakresy, zadania oraz oczekiwania zawiera Dyrektorium z 2020 roku. Wychodząc z wymiaru dydaktycznego podkreśla się wymiar związany z wiarą i ewangelizacją. Przypomina się, że pamięć stanowi element konstytutywny historii zbawienia. Lud Izraela zachęcany był do podtrzymywania żywej pamięci dobrodziejstw Boga. Żywa była ona w postawie Maryi. Katecheza, przywołując ważne wydarzenia i pamięć o nich, pragnie pomóc wierzącym czuć się uczestnikami

\footnotetext{
49 Por. DCG 73.

50 Por. KKK 22; DOK 154.

51 CT 55; por. DOK 154.

52 Por. DOK 155.
} 
owych wydarzeń. Pamięć stanowi ważny klucz w przekazie Objawienia. W tradycji od początku istnienia Kościoła wierni mieli obowiązek znać wyznanie wiary na pamięć, by pozostawało żywe w umyśle i sercu. Katecheza po objaśnieniu tekstów pomagała w ich zgłębianiu i zapamiętywaniu, by pozostawały źródłem życia chrześcijańskiego. Podkreśla się też wielkie znaczenie wspomnianego traditio i redditio53.

\section{Aktywność i kreatywność katechizowanego}

Dyrektorium z 1971 roku, uznając, iż w katechezie należy pobudzać aktywność wiary, nadziei i miłości ${ }^{54}$ zauważało, że katechizowany nie jest jedynie biernym odbiorcą prawdy objawionej, a jego wkład nie ogranicza się do uczestnictwa, wysłuchania, poznani prawdy i życiowego odesłania czy modlitwy. Katecheza w swojej działalności nie ogranicza się wyłącznie do kierowania się zasadami i metodami jedynie związanymi z objawieniem, ale przeszczepiając z dydaktyki świeckiej skuteczne i efektywne zasady i metody pragnie uczynić $\mathrm{z}$ nich postulat wychowania właściwej świadomości młodego chrześcijanina. Wszelkie kształcenie i prawdziwe przekazywanie wiadomości domagają się, by umożliwić i pobudzić wewnętrzną aktywność adresata ${ }^{55}$.

Nadrzędnym celem działalności edukacyjnej jest wszechstronny rozwój adresata. Wymaga on harmonijnego realizowania zadań w zakresie nauczania, kształtowania umiejętności i postaw, wychowania, a w miarę możliwości wtajemniczenia, aktywności wiary, nadziei i miłości. Zadania te tworzą wzajemnie uzupełniające się i równoważne wymiary pracy katechety. $Z$ jego strony nie wystarczy przekazywać treści, ale dynamizować wspólnotę; wymaga się niesienia pomocy w pobudzeniu wewnętrznym, wspierania, wzbudzania aktywności emocjonalnej, intelektualnej, sensomotorycznej i werbalnej. Ze strony katechizowanego zaś oczekuje się kreatywnego, zaangażowanego, kompetentnego poszukiwania, analizowania, wnioskowania, podejmowania decyzji i odpowiedzialnego działania. Staje się to pomocne i niezbędne w przyjęciu słowa Bożego, nawróceniu i praktykowaniu chrześcijańskiego życia.

Zagadnienie to podejmuje Dyrektorium z 1997 roku: „młodzi nie mogą więc być uważani tylko za przedmiot katechezy, ale za „czynny podmiot, aktywnych uczestników ewangelizacji i twórców społecznej odnowy" ${ }^{\text {" }}$.

Każda forma aktywności wymaga zastosowania odpowiednich metod i technik, sprzyjających optymalizacji działania. Katecheza przekazuje określone treści, a z drugiej strony katechizowani sami odkrywają wartości i się nimi dzielą. Nie

53 Por. DK 201-203.

54 Por. DCG 75.

55 Por. DCG 75.

56 DOK 183. 
można dzisiaj wyobrazić sobie katechezy bez aktywnego udziału w niej katechizujących i katechizowanych. Postawa czynna i twórcza wszystkich staje się podstawowym wymogiem.

Aktywne uczestnictwo katechizowanych jest zgodne z ekonomią objawienia i zbawienia, autentyczną komunikacją międzyludzką, bowiem wierzący, będąc wezwani do indywidualnej i grupowej odpowiedzi, w ten sposób odpowiadają na dar Boży przez modlitwę, uczestnictwo w sakramentach, innych czynnościach liturgicznych, zaangażowanie eklezjalne i społeczne, praktykę miłości, rozwijanie wartości ludzkich ${ }^{57}$.

Dorośli podejmując się tego zadania mogą przyczyniać się do doskonalenia katechezy, wskazując najskuteczniejsze drogi zrozumienia i wyrażenia orędzia. Niezbędne jest jednak pytanie ich o rozumienie chrześcijańskiego orędzia, udzielenia własnej odpowiedzi, skonfrontowania z nauką Kościoła, przyjmując jedynie to, co zgodne z wiarą, by znaleźć solidną pomoc w przekazie. Oni mogą wnieść owocny wkład do rozwoju katechezy, wskazując najbardziej skuteczne drogi zrozumienia i wyrażenia orędzia, takie jak „zrozumienie w czynie”, zaangażowanie w poszukiwaniu i dialogu, wymiana i porównywanie punktów widzenia ${ }^{58}$.

\section{Wspólnota}

Kontynuatorem misji Jezusa Chrystusa jest Kościół zjednoczony wokół Jego osoby. Wspólnota wierzących jest pierwszym podmiotem katechezy. Jak zaznaczał Paweł VI w adhortacji Evangelii nuntiandi: „ci, którzy szczerym sercem przyjmują Dobrą Nowinę, mocą tejże Nowiny oraz wspólnej wiary gromadzą się w imię Jezusa, ażeby razem szukać Królestwa, budować je i wprowadzać je do swego życia. I tak tworzą wspólnotę, która z kolei staje się głosicielką Ewangelii. (...) Ci więc, którzy tę nowinę przyjęli i jej mocą gromadzą się we wspólnotę zbawienia, mogą i powinni przekazywać ją i rozpowszechniać" ${ }^{29}$. Wagę tego podkreślają wszystkie wspominane tutaj dokumenty, choć różnie je określając: Dyrektorium z 1971 roku - zespoły, z 1997 roku - wspólnota, z 2020 roku - grupa.

Wspólnota - grupa - odgrywa ważną rolę w procesie rozwoju osób. W katechezie dzieci zespół pełni zadanie pomocnicze w przygotowaniu do życia społecznego, ich socjalizacji. W odniesieniu do dorastających dzieci i młodzieży należy uznać to za konieczność życiową w formowaniu osobowości. W niej się poznają, wspomagają i pobudzają do działania. W odniesieniu do dorosłych zespół uznaje się za warunek

\footnotetext{
57 Por. DCG 75; DOK 157.

58 Por. tamże.

59 EN 13.
} 
skuteczności katechezy, bowiem stawia sobie jako zadanie pobudzenie do poczucia chrześcijańskiej współodpowiedzialności oraz dialogu ${ }^{60}$.

Pedagogia katechetyczna jest skuteczna w takiej mierze, w jakiej wspólnota chrześcijańska staje się konkretnym i wzorczym punktem odniesienia dla drogi wiary pojedynczych osób. Ma to miejsce, gdy wspólnota staje się źródłem, miejscem i celem katechezy. Stając się żywym i stałym środowiskiem wiary, troszczy się o jej wzrost u wszystkich członków ${ }^{61}$. Grupa będąc czynnikiem dydaktycznym jest wezwana, by być miejscem doświadczeniem wspólnoty, formą uczestnictwa w życiu eklezjalnym, znajdując we wspólnocie eucharystycznej swój cel i pełny wyraz ${ }^{62}$.

W zespołach młodzieży i dorosłych katecheza przybiera formę wspólnego poszukiwania i odkrywania wzajemnych powiązań treści chrześcijańskiego orędzia z doświadczeniami zespołu. Prowadzona w ten sposób katecheza pozwoli młodym dostrzec, że Kościół nie jest czymś zewnętrznym w relacji do ich egzystencji, lecz zadaniem, za które wszyscy ponoszą odpowiedzialność. Konstruktywna interakcja między różniącymi się od siebie sprawia, że grupa staje się miejscem, gdzie kwitnie głęboka wymiana i porozumienie. Intensywność i skuteczność interakcji przyczyniają się do wspierania rozwoju uczestników.

Jako rzeczywistość eklezjalna grupa ożywiana jest przez Ducha Świętego, sprawcę każdego procesu wiary. Otwarcie na łaskę nie umniejsza korzystania z dyscyplin pedagogicznych, postrzegających grupę jako rzeczywistość społeczną, rządząca się własną dynamiką i prawami rozwoju. Umiejętne wykorzystanie tej wiedzy może wzmocnić poczucie utożsamienia się ze wspólnotą, konstruktywnie przezwyciężyć napięcia międzyludzkie, ułatwić proces interioryzacji wiary. Każda dynamika grupowa ma swoją kulminację w zgromadzeniu niedzielnym, gdzie doświadcza się spotkania z Panem i braterstwa, dojrzewania do służby i dawania świadectwa ${ }^{63}$.

Katecheta występuje w imieniu Kościoła jako świadek chrześcijańskiego orędzia; służy dzieląc się owocami swojej dojrzałej wiary, dokłada starań, by grupa prawdziwie przeżyła doświadczenie wspólnoty jako najbliższe życiu Kościoła, najdobitniej wyrażające się w sprawowaniu Eucharystii, mądrze kieruje do osiągnięcia zamierzonego celu. Obok wspólnotowego głoszenia i przekazywania wiary niezbędne są kontakty osobiste ${ }^{64}$.

\footnotetext{
60 Por. DCG 76; DOK 159; DK 219.

61 Por. DOK 158.

62 Por. DOK 159.

63 Por. DK 220.

64 Por. DCG 74; DOK 159; DK 219.
} 


\section{Język}

Istotnym elementem metodycznym dla wprowadzenia w życie wiary jest język. Już w momencie powstawania Dyrektorium w 1971 roku zauważono, że nie wystarcza język neoscholastyczny, deharbowski, dla niektórych niezrozumiały w pełni był także biblijny czy liturgiczny. Język współczesny nie zawsze oddawał istotę misterium i Objawienia. Catechesi tradendae zwracało uwagę na niezbędność języka odpowiedniego do przekazywania Credo ${ }^{65}$.

Jedynie Dyrektorium z 2020 roku wśród elementów metodologii szeroko wskazuje na język. W pozostałych porusza się tę kwestię w innych kontekstach. Dyrektorium z 1971 roku dostrzegało, że język współczesny nie zawsze oddawał istotę misterium i Objawienia. Dyrektorium z 1997 roku, podejmując kwestię katechezy w kontekście społeczno- kulturowym, mówi o języku: „w procesie inkulturacji Ewangelii katecheza nie powinna się bać użycia tradycyjnych formuł i technicznych pojęć wiary, ale powinna nadać im znaczenie i pokazać ich nośność egzystencjalną; z drugiej strony zadaniem katechezy jest, by znalazła ona język odpowiedni dla wszystkich współczesnych dzieci, młodzieży i innych kategorii ludzi: język właściwy dla studiujących i naukowców; język dla analfabetów, nieuczonych albo stojących na niskim stopniu cywilizacji, nawet dla upośledzonych fizycznie czy umysłowo i innych"66.

Inkulturacja wiary dokonuje się drogą języka. Stanowi on konstytutywny element doświadczenia człowieka. Katecheza, będą działaniem pedagogicznym, w odniesieniu do ludzi różnych kultur, środowisk, historii wieku, życia duchowego oraz sytuacji społecznej, posługujących się własnym językiem w głoszeniu wiary musi dostosować się i wykorzystać język tej wspólnoty. Podobnie każde ze źródeł katechezy posiada swój własny język ${ }^{67}$. Katecheza musi dokonywać odpowiedniej inkulturacji, włączając roztropnie język, symbole i wartości kultury, w której żyją katechumeni i katechizowani ${ }^{68}$, przekazując orędzie ewangeliczne w jego integralności i czystości, troszcząc się o wierne przekazywanie całego orędzia chrześcijańskiego ${ }^{69}$, wykładając w sposób dostosowany do zdolności adresatów, nie redukując jego wymagań $\mathrm{w}$ obawie przed odrzuceniem ${ }^{70}$. Wymaga to przełożenia trzonu ewangelizacyjnego orędzia bez zmiany prawdy na język zrozumiały dla miejscowych ludzi, by później w tym języku głosić. Wynika z tego niekończące się zadanie znalezienie języka, zdolnego do komunikowania słowa Bożego i Credo Kościoła ${ }^{71}$.

\footnotetext{
65 Por. CT 59.

66 DOK 208.

67 Por. DOK 96.

68 Por. tamże 110.

69 Por. DCG 38.

70 Por. DOK 112.

71 Por. tamże 146.
} 
Dyrektorium z 2020 roku podejmuje obszernie ten element metodologii. Kościół od początku swojej historii przekazywał wiarę przez Pismo Święte (język biblijny), symbole i obrzędy liturgiczne (język symboliczno-liturgiczny), pisma Ojców Kościoła, Symbole wiary, stwierdzenia Magisterium (język doktrynalny) oraz świadectwa świętych i męczenników (język performatywny). Przez te główne języki wiary wierni mogą dysponować wspólnym językiem porozumienia się ${ }^{72}$. Katecheza kreatywnie przyjmuje języki kultur narodów, wspólnotom kościelnym pomaga poszukiwać nowych języków dostosowanych do odbiorców, stając się dzięki temu miejscem inkulturacji wiary ${ }^{73}$.

Zauważając, że katecheza czyni użytek z każdego języka, który pomaga realizować zadania, szczególną uwagę kieruje się na język narracji oraz autobiograficzny. $\mathrm{W}$ renesansie narracji w ostatnich latach widzi się go nie tylko jako narzędzie językowe, ale drogę, przez którą człowiek poznaje siebie i otaczającą rzeczywistość oraz nadaje znaczenie temu, co przeżywa. Również wspólnota Kościoła staje się coraz bardziej świadoma narracyjnej tożsamości wiary. Podobnie jak rodzina w ciągu wieków w różnych formach przybliżał opowieść o historii zbawienia. Język ten posiada zdolność harmonizowania wszystkich języków wiary wokół misterium paschalnego, angażuje człowieka we wszystkich wymiarach: uczuciowym, poznawczym, wolitywnym. Wartość jej uwydatnia się w tym, że owocnie splata się historia Jezusa, wiara Kościoła i życie tych, którzy opowiadają i słuchają ${ }^{74}$.

W odniesieniu do języka sztuki kieruje się uwagę na obrazy, dziedzictwo muzyczne i sztukę współczesną. Obrazy w sztuce chrześcijańskiej stanowią pomoc postrzegania zmysłowego, pomagają odczuć, że Pan żyje i jest obecny, działa w Kościele i historii. Stanowią także język wiary. Repertorium ikonograficzne pierwszego tysiąclecia, stanowiące wspólne dziedzictwo niepodzielonego Kościoła, odegrało znaczącą rolę w ewangelizacji. Dzisiaj obrazy mogą pomóc w doświadczeniu spotkania z Bogiem przez kontemplację piękna, przenosząc spotkanie Innego. Biblia pauperum umożliwiała w historii szybsze poznanie i zapamiętywanie wydarzeń historii zbawienia. Obrazy dotykają serca i uwewnętrzniają przesłanie. Nieocenioną wartość posiada dziedzictwo muzyczne (szczególnie muzyki kościelnej), będąc nośnikiem wiary i stanowiąc drogocenny środek ewangelizacji, bowiem zaszczepia ono pragnienie nieskończoności. Bogactwo doktrynalne, przekazywane dźwiękami muzyki łatwiej wnika do umysłu i głębiej odciska się w sercu. Kościół, który wchodził w interakcje $\mathrm{z}$ różnymi formami wyrazu artystycznego jest też wezwany dzisiaj, by przy zachowaniu słusznego zmysłu krytycznego otwierał się na sztukę współczesną. Posiadają one zdolność otwierania człowieka na język zmysłów, dzięki czemu nie pozostaje się jedynie widzem, ale podejmuje się aktywnego udziału. Doświadczenie artystyczne, przenikające intensywne poszukiwanie

72 Por. DK 205.

73 Por. tamże 206.

74 Por. tamże 207-208. 
sensu i duchowości może być pomocne w nawróceniu zmysłów, będącym częścią drogi wiary ${ }^{75}$.

Nowym wyzwaniem dla Kościoła stają się język i narzędzia cyfrowe ${ }^{76}$. Narzędzia te są powszechnie stosowane w dydaktyce. Kościół przyzwyczajony do komunikacji jednokierunkowej - głosząc, nauczając, przedstawiając istotę dogmatów (a tekst pisany z trudem przebija się do ludzi młodych, przyzwyczajonych do tego, że słowo pisane uzupełniane jest językiem dźwięków i obrazu) - staje wobec nowych dróg komunikacji. Nowe technologie wytworzyły nową infrastrukturę kultury. W przestrzeni wirtualnej, przyjmowanej przez wielu jak realną, pozyskuje się wiadomości, wypracowuje i wyraża się opinie, uczestniczy w dyskusjach, poszukuje odpowiedzi. Cyfrowe formy komunikacji jako otwarte na interakcję dają nowe możliwości. Zachodzi potrzeba, poza wiedzą technologiczną, przyswojenia sobie nowych sposobów efektywnej komunikacji a także zadbanie o obecność w sieci, która będzie świadectwem wartości ewangelicznych. Technologie informacyjne i komunikacyjne stanowią owoc rzeczywistej interakcji międzyludzkiej. Media społecznościowe i urządzenia cyfrowe ułatwiają współpracę, wymianę doświadczeń oraz poznanie, stąd mogą być nie tylko narzędziem ewangelizacji, ale czynnikiem rozwoju człowieka. Priorytetem dla katechezy jest wychowanie do umiejętności właściwego korzystania z tych narzędzi, a katecheta świadomy wielkiego ich wpływu zwłaszcza na najmłodszych. Rzeczywistość wirtualna nie może jednak zastąpić rzeczywistości duchowej, eklezjalnej, sakramentalnej oraz bezpośredniego przeżywania spotkania osób. „Aby dawać świadectwo Ewangelii, konieczna jest autentyczna komunikacja, która stanowi owoc rzeczywistej interakcji między ludźmi"77.

W tym kontekście należy wspomnieć, iż Dyrektorium z 1997 roku, wśród elementów metodologii wymienia środki masowego przekazu ${ }^{78}$ stwierdzając, iż współczesnym „pierwszym areopagiem” jest świat środków przekazu, które dla wielu stały się głównym narzędziem informacyjnym i formacyjnym, przewodnikiem i natchnieniem $w$ życiu indywidualnym, rodzinnym i społecznym. Z tego też względu, oprócz wykorzystania w katechezie i ewangelizacji środków tradycyjnych, wykorzystanie ich nabrało istotnego znaczenia. Zalicza do nich telewizję, radio, prasę, płyty, taśmy magnetofonowe, video, dyski kompaktowe, cały sektor urządzeń audiowizualnych - przy świadomości tego, że każdy wymaga specyficznego zastosowania, poszanowania i dowartościowania. W dobrze zaprogramowanej katechezie takie środki winny być uwzględnione ${ }^{79}$. Wymaga to od katechety troski o ich poznanie oraz kompetencji. Przede wszystkim jednak, ze względu na silny

\footnotetext{
75 Por. DK 209-212.

76 Szerzej problematykę katechezy w odniesieniu do kultury cyfrowej Dyrektorium podejmuje w p. $359-372$

77 DK 213-217.

78 Por. DOK 160-162.

79 Por. DOK 160.
} 
wpływ na kulturę, do której kształtowania przyczyniają się środki społecznego przekazu, nie należy zapominać, że „nie wystarcza używać ich do szerzenia orędzia chrześcijańskiego i Magisterium Kościoła, ale trzeba włączyć samo orędzie w tę nową kulturę, stworzoną przez nowoczesne środki przekazu... z nowymi językami, nowymi technikami, nowymi postawami psychologicznymi" "80. Tylko w ten sposób, z łaską Bożą, orędzie ewangeliczne jest zdolne przeniknąć do świadomości każdego „oraz wzbudzić najbardziej osobiste przylgnięcie do niego i zaangażowanie"81. Rodzi to wyzwania wobec katechetów w trosce o pracowników tychże środków, by pracownicy środków i ich odbiorcy mogli uzyskać łaskę Ewangeliii ${ }^{82}$.

W kontekście języka Dyrektorium zaznacza: „,w procesie inkulturacji Ewangelii katecheza nie powinna się bać użycia tradycyjnych formuł i technicznych pojęć wiary, ale powinna nadać im znaczenie i pokazać ich nośność egzystencjalną; $z$ drugiej strony zadaniem katechezy jest, „by znalazła ona język odpowiedni dla wszystkich współczesnych dzieci, młodzieży i innych kategorii ludzi: język właściwy dla studiujących i naukowców; język dla analfabetów, nieuczonych albo stojących na niskim stopniu cywilizacji, nawet dla upośledzonych fizycznie czy umysłowo i innych"83.

\section{Przestrzeń}

Wskazana przez Dyrektorium z 2020 roku przestrzeń, będąca drogą komunikacji ewangelizacyjnej stanowi jego novum. Każda kultura, społeczeństwo czy wspólnota obok własnego języka, słów i obrazów, za pomocą których się komunikuje dokonuje tego za pomocą przestrzeni. Kościół czynił to wykorzystując elementy architektury służące gromadzeniu wiernych i wypełnianiu zadań: sprawowania Bożych misteriów, braterskiego dzielenia się i nauczania; prowadzenia działalności apostolskiej i charytatywnej, formacyjnej, socjalizacji. Przykładem pozostają wczesnochrześcijańskie budowle, wyposażone w specjalną przestrzeń zwaną narteksem. Dzięki zamieszczanym tam obrazom scen biblijnych stawały się one miejscem katechezy.

Przestrzenie wykorzystywane jako miejsce katechizacji to miejsca wyrażania przez wspólnotę swojego sposobu ewangelizowania. Potrzeba, by były to miejsca przyjazne i zadbane, pozwalające odczuć atmosferę rodzinnej zażyłości oraz harmonijne włączenie się we wspólnotowe działanie. Rodzi to wyzwanie wobec pomieszczeń przypominających sale szkole, by ich przystosowanie efektywniej służyło katechezie.

\footnotetext{
80 DOK 162.

81 Tamże.

82 Por. DOK 161.

${ }^{83}$ Por. DOK 209.
} 
Dyrektorium zachęca też, by jako miejsce odbywania katechezy doraźnej wykorzystać takie, które nie pokrywają się z miejscami przypisywanymi wspólnocie chrześcijańskiej, m.in. domy, osiedla, placówki wychowawcze, kulturalne, rekreacyjne, więzienia. To w nich tworzą się relacje rodzinne, a katecheza powiązana z życiem codziennym może lepiej przemawiać do odbiorców ${ }^{84}$.

Osiągnięcie zamierzonego celu w działalności katechetycznej wymaga stosowania określonego układu czynności katechety i adresata, uwzględnienia fizycznego i duchowego etapu rozwojowego katechizowanego, możliwości środowiska, doboru i stosowania różnorodnych metod, narzędzi, języka. Wartość metody zależy od tego w jakim stopniu stoi ona w służbie dialogu miłości Boga z każdą osobą, Objawienia i nawrócenia.

Słowa kluczowe: katecheza, katecheta, metoda, doświadczenie człowieka, pamięć, aktywność i kreatywność katechizowanego, wspólnota, język, przestrzeń.

\section{Summary}

The subject of this work is to analyze the methodological elements published in the years $1971-2020$ in the catechetical directories. It is noticeable that there are some constant elements raised differently in different periods of time and that new elements emerge as well as a result of the development of reflection, from Church documents and concrete situations of Church in the environment, which inspires a new model of catechetical activity. Changes in the approach along with the achievements of secular science, such as pedagogy, psychology, educational sociology, interpersonal communication and new digital technologies are the sign of natural evaluation arising from the essence of the Church as a live organism. It does not mean that the Church rejects the previous legacy and tradition.

Keywords: catechesis, catechist, method, human experience, memory, activity and creativity of a disciple, community, language, space.

\section{Riassunto}

Oggetto di questo studio si focalizza sull'analisi di elementi metodologici dei direttori catechetici pubblicati negli anni 1971-2020. Essa permette di rilevare l'esistenza di alcune entità durature, seppure affrontati differentemente nei diversi periodi, el'emergere dei nuovi, derivanti dallo sviluppo di riflessioni, documenti della Chiesa o derivanti da situazioni specifiche della Chiesa nella società, sucitando un nuovo modello di attività catechetica. Cambiamenti nell'approccio, compresi i risultati impiegati dalle scienze secolari come la pedagogia, la psicologia dello sviluppo, la sociologia dell'educazione, la comunicazione interpersonale, le nuove tecnologie digitali, che manifestano la scoperta dei segni dei tempi, esprimono una valutazione naturale che scaturisce dall'essenza della Chiesa come organismo vivente, e non dal rigetto di precedenti conquiste e tradizioni.

84 Por. DK 221-223. 
Parole chiavi: catechesi, catechista, metodo, esperienza umana, memoria, attività e creatività del catechista, comunità, lingua, spazio.

\section{Bibliografia}

Benedykt XVI, Adhortacja apostolska Verbum Domini, Watykan 2010.

Franciszek, Adhortacja apostolska Evangelii gaudium, Watykan 2013.

Jan Paweł II, Adhortacja apostolska Catechesi tradendae, Watykan 1979.

Katechizm Kościoła Katolickiego, Poznań 1994.

Konferencja Episkopatu Polski, Dyrektorium katechetyczne Kościoła katolickiego w Polsce, Kraków 2001.

Kongregacja ds. Duchowieństwa, Directorium catechisticum generale, Watykan 1971.

Kongregacja ds. Duchowieństwa, Dyrektorium ogólne o katechizacji, Watykan 1997.

Papieska Rada ds. Krzewienia Nowej Ewangelizacji, Dyrektorium o katechizacji, Kielce 2020.

Paweł VI, Adhortacja apostolska Evangelii nuntiandi, Watykan 1975.

Jan Paweł II, Wierze w Boga Ojca Stworzyciela, Watykan 1987.

Kiciński A., Rozwój dyrektoriów katechetycznych po Soborze Watykańskim II (1971-1997-

2010), „Roczniki Teologiczne” 67(2020)11, s. 5-27.

Kubik W. (red), Katecheza po Soborze Watykańskim II w świetle dokumentów Kościoła 1, Warszawa 1985.

Kubik W. (red), Katecheza po Soborze Watykańskim II w świetle dokumentów Kościoła 2, Warszawa 1985.

Panuś T., Geneza i główne wskazania Dyrektorium ogólnego o katechizacji, „Studia Katechetyczne" 13(2012), s. 11-34.

Szpet J. (red), Katecheta wychowawca kreatywnego i refleksyjnego ucznia. Katecheza, rodzina, parafia i szkoła, Poznań 2009.

Szpet J. (red), Wspomaganie zintegrowanego rozwoju ucznia. Katecheza, rodzina, parafia i szkoła, Poznań 2014.

Tomasik P., Charakterystyka „Dyrektorium ogólnego o katechizacji” w: Katecheza Kościoła w świetle „Dyrektorium ogólnego o katechizacji”, pr. zbiorowa, Kraków 1999, s. 44-65.

\section{O autorze}

ks. Jan SZPET - profesor dr. hab. teologii w zakresie katechetyki, konsultor Komisji Wychowania Katolickiego Konferencji Episkopatu Polski i jej rzeczoznawca ds. oceny programów i podręczników katechetycznych, współautor 17 programów nauczania, współautor i redaktor 125 pomocy dydaktycznych 